\title{
Angiogenesis in Breast Cancers without Lymph Node Metastasis
}

\author{
Lenf Nodu Metastazı Olmayan Meme Kanserlerinde Angiogenez
}

\author{
Nusret ERDoĞAN, Aylin DENGizMEN, Ayşenur AKYILDIZ iĞDEM, Elife ŞAHAN, Ümit SEZA TETiKKURT
}

Department of Medical Pathology, Taksim Education and Research Hospital, iSTANBUL, TURKEY

\begin{abstract}
Objective: Many studies have been focused on angiogenesis as a possible prognostic factor, recently. In this study, we evaluated microvessel density by CD34 in primary tumors of the patients with lymph node negative breast carcinomas and compared the results with prognostic parameters.
\end{abstract}

Material and Method: 31 patients with invasive breast carcinomas without axillary lymph node metastasis were included in this study. Microvessel density was assessed by CD34 staining in the primary tumor and compared with the tumor type and prognostic parameters such as age, tumor size, nuclear grade, lymphatic vessel invasion, and estrogen and progesteron reseptor status. CD34 staining was evaluated in three areas by $\mathrm{x} 200$ magnification.

Results: The mean value microvessel density of CD34 staining in the primary tumor was 43 (minimum 19 and maximum 100). There was a significant relationship between microvessel density and progesterone receptor expression. microvessel density was higher in lobular type breast carcinoma.

Conclusion: The correlation between progesterone receptor status and microvessel density should be further confirmed by prospective studies. The high microvessel density rate in lobular carcinoma may be attributed to abundance of stromal cells or to the low number of patients.

Key Words: Breast cancer, Metastasis, Angiogenesis, Progesterone receptor

\section{ÖZ}

Amaç: Son yıllarda anjiogenez üzerinde oldukça sık durulmakta ve bu konuda çeşitli çalışmalar yapılmaktadır. Bu çalışmada lenf nodu negatif tanısı alan meme kanserli hastaların primer tümör kesitlerinde CD34 antikoru ile mikrodamar yoğunluğunu tespit ettik ve elde ettiğimiz sonuçları primer tümör özellikleriyle karşılaştırdık.

Gereç ve Yöntem: Aksiller lenf nodu metastazı olmayan 31 invaziv meme kanserli hasta çalışma kapsamına alındı. Bu hastaların primer tümör kesitleri üzerinde CD34 antikoru ile mikrodamar yoğunluğu incelendi ve yaş, tümör boyutu, nükleer grade, lenfovasküler invazyon, östrojen ve progesteron reseptörleri gibi prognostik parametrelerle ve tümör tipiyle karşılaştırıldı. CD34 boyanması üç alanda x200 büyütmede değerlendirildi.

Bulgular: Primer tümörde CD34 ile boyanan mikrodamar yoğunluğu ortalaması 43 (en az 19, en çok 100) olarak belirlendi. Mikrodamar yoğunluğu ile progesteron reseptörü pozitifliği arasında önemli bir ilişki bulundu. Lobüler karsinom vakalarında mikrodamar yoğunluğu yüksekti.

Sonuç: Mikrodamar yoğunluğu ile progesteron reseptörü arasındaki ilişki ileride yapılacak çalışmalarla desteklenmelidir. Lobuler karsinomda saptanan yüksek mikrodamar yoğunluğu stromal hücrelerin yoğunluğundan kaynaklanabileceği gibi olgu sayısının azlığına da bağlı olabilir.

Anahtar Sözcükler: Meme kanseri, Metastaz, Anjiogenez, Progesteron reseptörü 


\section{INTRODUCTION}

Factors other than cell kinetics modify the rate of tumor growth. Most important among these is the blood supply (1). Tumors can not enlarge beyond 1 to $2 \mathrm{~mm}$ in diameter unless they are vascularized (2). This is partly because of hipoxia-induced apoptosis (1). Angiogenesis is requisite not only for continuing tumor growth but also for metastasis (3). Without access to the vasculature tumor cells can not metastasize. Angiogenesis in breast carcinoma measured by microvessel density (MVD) is proved to have prognostic importance (4-11).

\section{MATERIALS AND METHOD}

The initial assesment of CD34 stained sections were done both at $40 \mathrm{x}$ and $100 \mathrm{x}$ magnification and 3 most intense vascularized fields were selected for counting. MVD in necrotic or low cellular fields and areas adjacent to benign breast tissue were no evaluated. Brown stained endothelial cells or group of endothelial cells and vessels clearly separated from neighbouring vessels were counted. Branching vessels were counted as one. The presence of a lumen or an eritrosit in a lumen was not requisite for determining a countable vessel. The counting was done in three fields at $\mathrm{x} 200$ magnification using Nikon E200 type microscope (x200 field size corresponds to $0.785 \mathrm{~mm}^{2}$ ).

\section{RESULTS}

Median age was 55 (minimum 35 and maximum 84 ). Median tumor size was 2.72 (minimum $1 \mathrm{~cm}$ and maximum is $7 \mathrm{~cm}$ ). 27 patients (87\%) were diagnosed as invasive ductal carcinoma and four as lobular carcinoma. (12.9\%). Histologic grade was given only for ductal carcinoma cases. The summary of the study results is given in Table I.

Median MVD value of CD34 stained sections in three areas (x200) was 43 (minimum 19 and maximum 100) (Figures 1 and 2). MVD was higher in the peripheral than in the central parts of tumors.

\section{The relationship between MVD and other parameters}

The results of the relationship between MVD and other parameters assesed by Fischer test was given in Table II.

We found a relationship between MVD and progesterone receptor expression. Besides, there was a weak correlation between NG and vessel density. However, this correlation was not proved by variance analysis (ANOVA).

\section{The relationship between MVD and tumor type}

Mann Whitney $\mathrm{U}$ and ANOVA tests were used to assess the relation between tumor type and MVD. The results are given in Table III. There was a relation between tumor type and MVD. Median MVD was 66.5 in lobular carcinoma and 39.8 in ductal carcinoma.

\section{DISCUSSION}

Studiesinvestigatingangiogenesisand prognostic parameters in invasive breast carcinoma revealed a relationship between MVD and histologic grade $(6,8,12)$. Gasparani et al also defined a relationship with premenapousal period and early age (6). Moreover, Bosari et al found that MVD is asscociated with vascular invasion (5). However, there

Table I: The group of cases for statistical assesment

\begin{tabular}{|l|r|}
\hline Age $\leq 47$ & $10(\% 32)$ \\
\hline Age $>47$ & $21(\% 68)$ \\
\hline Tumor diameter $\leq 2 \mathrm{~cm}$ & $12(\% 39)$ \\
\hline Tumor diameter $>$ cm & $19(\% 61)$ \\
\hline HG I-II & $15(\% 48)$ \\
\hline HG III & $12(\% 39)$ \\
\hline NG 1-2 & $23(\% 74)$ \\
\hline NG 3 & $8(\% 26)$ \\
\hline Duktal & $27(\% 87)$ \\
\hline Lobular & $4(\% 13)$ \\
\hline LVI $(+)$ & $13(\% 42)$ \\
\hline LVI $(-)$ & $18(\% 58)$ \\
\hline ER $(+)$ & $18(\% 58)$ \\
\hline ER(-) & $13(\% 42)$ \\
\hline PR $(+)$ & $23(\% 74)$ \\
\hline PR(-) & $8(\% 26)$ \\
\hline
\end{tabular}

HG: Histological grade, LVI: Lymphatic vessel invasion, PR: Progesterone receptor, NG: Nuclear grade, OR: Estrogen receptor

Table II: The correlation between MVD and other parameters

\begin{tabular}{|l|c|c|}
\hline Parameter & Fischer test & Anova \\
\hline NG & 0,124 & 0.138 \\
\hline LVI & 0,468 & \\
\hline ER & 0,532 & \\
\hline PR & 0,037 & 0.0295 \\
\hline Tumor diameter & 0,282 & \\
\hline Age & 0,394 & \\
\hline
\end{tabular}

Table III: The relationship between tumor type and MVD

\begin{tabular}{|l|c|c|}
\hline & Mann-Whitney U Test & Anova (p value) \\
\hline Tumor type & 0.053 & 0.014 \\
\hline
\end{tabular}


are also some studies detecting no correlation between angiogenesis and other well-known parameters $(7,13,14)$. In a unique study by Vameşu $S$ evaluating 158 needle core biopsies from breast cancer patients, high MVD was associated with negative progesterone receptor expression (15). In contrast, we found a positive relationship between progesteron receptor and MVD. Therefore, the correlation between PR status and MVD should be further investigated by large number of series.

We noticed an increase in MVD in 4 cases of lobular carcinoma. The difference in MVD between invasive ductal carcinoma and lobular carcinoma was statistically proven. Nakopoulou et al also found high MVD with factor VIII in invasive lobular carcinoma. However, they stated that they could not find the same difference with CD31. They also asserted invasive lobular carcinomas with high MVD had better prognostic parameters such as absence of metastasis and positive estrogen receptor expression (16). This can be explained by prominent number of stromal cells in invasive lobular carcinoma whih may react with endothelial cell markers. Compared to factor VIII and CD31, CD34 was shown to be the best in determining microvessels with no CD34 immunreactivity in tumor or inflammatory cells (17). Nevertheless, perivascular stromal cells may express CD34 (18). The high MVD rate in lobular carcinoma in our study may partly attributed to these stromal cells, since a precise judgment would not be made based on only four cases.

In a study investigating interobserver variability in deciding the most representative area showing intense staining (i.e. highest MVD), a significant difference was found between individual observers (19). Fridman et al pointed out that there may be a remarkable difference in staining intensity in different sections of the same paraffin block or in different blocks of the same tumor (14). There is a clear-cut difference in MVD (per $\mathrm{mm}^{2}$ ) in lymph node negative breast cancers in the literature (19). In the current study, we used the most accepted criteria by Weidner (4). We investigated MVD in one block including the peripheral portions of the tumor considering the previous studies reporting that these areas show more intense staining $(12,15,18)$. According to this criterion mean MVD value was 43 (in $0.79 \mathrm{~mm}^{2}$ ) in 31 cases of lymph node negative breast carcinoma. This value was close to Weidner's study in which a mean value of 45 (in $0.74 \mathrm{~mm}^{2}$ ) was found (4).

In their study Cunnick et al found high lyphangiogenesis rates with specific lymphatic markers in breast cancer compared to normal breast. In addition, carcinomas with regional lymph node metastasis showed high expression rates compared to those without metastasis (20). Abd El

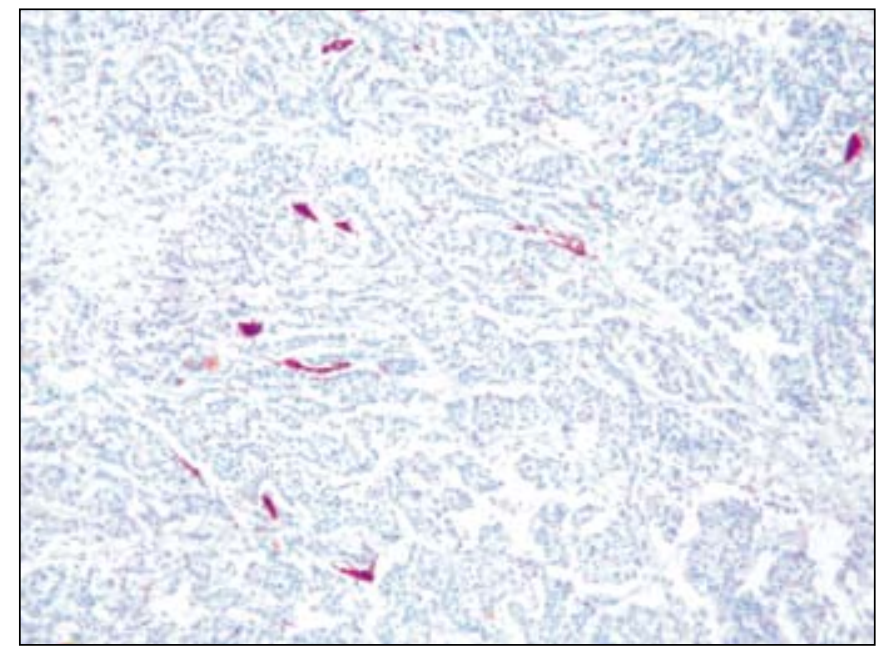

Figure 1: Low MVD in invasive ductal carcinoma (AEC, x100)

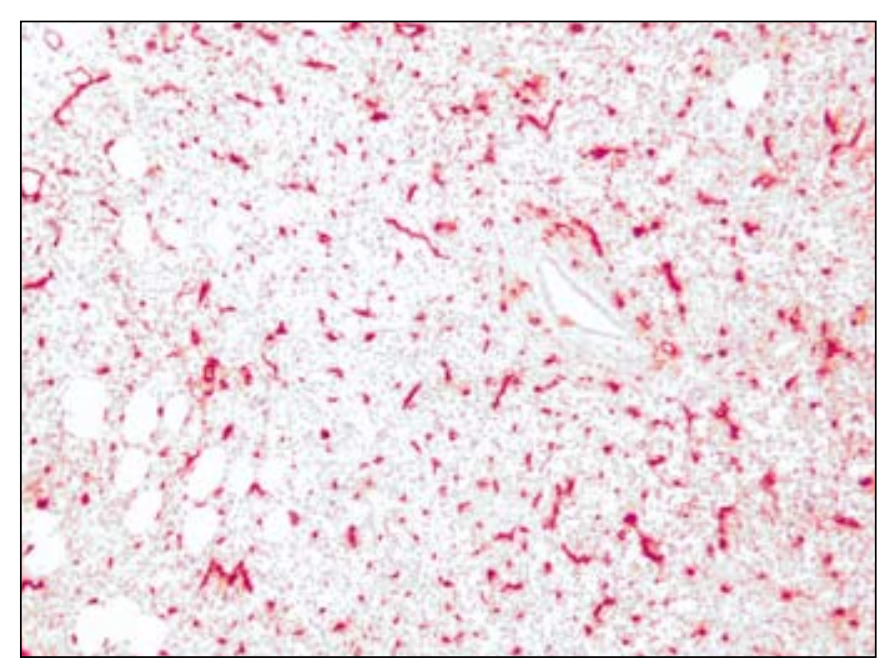

Figure 2: High MVD in invasive ductal carcinoma (AEC, x100)

Moneim et al found breast carcinomas with high MVD can predict metastasis in axillar lymph nodes. They also concluded that MVD has a useful effect on predicting not only prognosis but also the cases which will benefit from antiangiogenic therapies added to adjuvant therapies (21).

The prognostic value of angiogenesis is controversial. Many studies proved that MVD in invasive breast carcinoma has a prognostic value (4-10) although some others did not (1214). MVD is an important indicator of prognosis in lymph node negative breast carcinoma and also has an effect in determining those with poor prognosis $(6,8,11)$.

We think that the correlation of angiogenesis with progesterone status should be confirmed by prospective studies using different therapeutic strategies like antiangiogenic molecules. Although the high MVD in 
invasive lobular carcinoma in this study may be due to stromal cells or low number of patients the relation between angiogenesis and hormone receptors should also be clarified.

\section{REFERENCES}

1. Kumar V, Fausto N, Abbas A: Pathologic Basis of Disease. 7 ed. Saunders, Philadelphia, 2005, 1129-1148

2. Fidler IJ, Ellis LM: The implications of angiogenesis for the biology and therapy of cancer metastasis. Cell. 1994, 79:185-188

3. Pluda JM: Tumor-associated angiogenesis: mechanisms, clinical implications, and therapeutic strategies. Semin. Oncol 1997, 24:203-218

4. Weidner N, Semple JP, Welch WR, Folkman J: Tumor angiogenesis and metastasis-correlation in invasive breast carcinoma. N Engl J Med 1991, 324:1-8

5. Bosari S, Lee AK, DeLellis RA, Wiley BD, Heatley GJ, Silverman $M L$ : Microvessel quantitation and prognosis in invasive breast carcinoma. Hum. Pathol. 1992, 23:755-761

6. Gasparini G, Weidner N, Bevilacqua P, Maluta S, Dalla Palma P, Caffo O, Barbareschi M, Boracchi P, Marubini E, Pozza F: Tumor microvessel density, p53 expression, tumor size, and peritumoral lymphatic vessel invasion are relevant prognostic markers in node-negative breast carcinoma. J. Clin. Oncol. 1994, 12:454-466

7. Ogawa Y, Chung YS, Nakata B, Takatsuka S, Maeda K, Sawada T, Kato Y, Yoshikawa K, Sakurai M, Sowa M: Microvessel quantitation in invasive breast cancer by staining for factor VIIIrelated antigen. Br J Cancer. 1995, 71:1297-1301

8. Bevilacqua P, Barbareschi M, Verderio P, Boracchi $P$, Caffo O, Dalla Palma P, Meli S, Weidner N, Gasparini G: Prognostic value of intratumoral microvessel density, a measure of tumor angiogenesis, in node-negative breast carcinoma--results of a multiparametric study. Breast Cancer Res. and Treat. 1995, 36:205-217

9. Karaiossifidi H, Kouri E, Arvaniti H, Sfikas S, Vasilaros S: Tumor angiogenesis in node-negative breast cancer: relationship with relapse free survival. Anticancer Res. 1996, 16:4001-4002

10. Heimann R, Ferguson D, Gray S, Hellman S: Assessment of intratumoral vascularization (angiogenesis) in breast cancer prognosis. Breast Cancer Res. and Treat. 1998, 52:147-158
11. Arora $R$, Joshi $K$, Nijhawan $R$, Radotra BD, Sharma SC: Angiogenesis as an independent prognostic indicator in nodenegative breast cancer. Anal Quant Cytol Histol. 2002, 24:228233

12. Van Hoef ME, Knox WF, Dhesi SS, Howell A, Schor AM: Assessment of tumour vascularity as a prognostic factor in lymph node negative invasive breast cancer. Eur. J. Cancer. 1993, 29A:1141-1145

13. Aranda FI, Laforga JB: Microvessel quantitation in breast ductal invasive carcinoma. Correlation with proliferative activity, hormonal receptors and lymph node metastases. Path. Res. Pract. 1996, 192:124-129

14. Fridman V, Humblet C, Bonjean K, Boniver J: Assessment of tumor angiogenesis in invasive breast carcinomas: absence of correlation with prognosis and pathological factors. Virchows Arch. 2000, 437:611-617

15. Vameșu S: Angiogenesis and progesterone receptor status in primary breast cancer patients: an analysis of 158 needle core biopsies. Rom J Morphol Embryol 2007, 48:267-274

16. Nakopoulou L, Lekkas $N$, Lazaris AC, Athanassiadou $P$, Giannopoulou I, Mavrommatis J, Davaris P: An immunohistochemical analysis of angiogenesis in invasive breast cancer with correlations to clinicopathologic predictors. Anticancer Research. 1999, 19:4547-4554

17. Martin L, Green B, Renshaw C, Lowe D, Rudland P, Leinster SJ, Winstanley J: Examining the technique of angiogenesis assessment in invasive breast cancer. Br J Cancer. 1997, 76:10461054

18. Weidner $N$ : Current pathologic methods for measuring intratumoral microvessel density within breast carcinoma and other solid tumors. Breast Cancer Res. and Treat. 1995, 36:169180

19. Vermeulen PB, Libura M, Libura J, O'Neill PJ, van Dam P, Van Marck E, Van Oosterom AT, Dirix LY: Influence of investigator experience and microscopic field size on microvessel density in node-negative breast carcinoma. Breast Cancer Res. and Treat. 1997, 42:165-172

20. Cunnick GH, Jiang WG, Jones TD, Watkins G, Gomez KF, Morgan MJ, Subramanian A, Mokbel K, Masel RE: Lymphangiogenesis and lymph node metastasis in breast cancer. Molecular Cancer 2008, 7:23. doi:10.1186/1476-4598-7-23

21. Abd El-moneim N, Ebid Abd El-moneim S, Kazem A, Saad A, Mousa S, El-abd E, Hewala T: The role of angiogenesis assesment in the prognosis of breast carcinoma and in the evaluation of the therapeutic effect of 'shark care' drug as an angiogenesis inhibitor; Turk J Cancer 2008, 38:123-124 